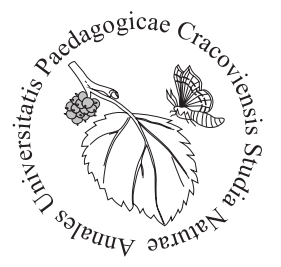

Annales Universitatis Paedagogicae Cracoviensis Studia Naturae, 3 (supplement): 7-16, 2018, ISSN 2543-8832

DOl: $10.24917 / 25438832.3$ supp.1

Mateusz Ciepliński ${ }^{1 *}$, Mariusz Kasprzak ${ }^{1}$ Monika Grandtke ${ }^{1}$, Aleksandra Steliga² ${ }^{2}$ Piotr Kamiński ${ }^{1,3}$, Leszek Jerzak ${ }^{1}$

${ }^{1}$ Faculty of Biological Sciences, University of Zielona Góra, Prof. Z. Szafrana Str., 65-516 Zielona Góra, Poland, *m.cieplinski@wnb.uz.zgora.pl ${ }^{2}$ Department of Health Sciences, Pomeranian University of Słupsk, 64 Bohaterów Westerplatte Str., 76-200 Słupsk, Poland ${ }^{3}$ Department of Medical Biology and Biochemistry, Department of Ecology and Environmental Protection, Faculty of Medicine, Collegium Medicum in Bydgoszcz, Nicolaus Copernicus University in Toruń, 9M. Skłodowskiej-Curie, 85-094 Bydgoszcz, Poland

\title{
The impact of UDN on selectwed blood parameters of female sea trout Salmo trutta m. trutta L. spawners
}

Introduction

Sea trout - Salmo trutta morpha trutta L. (Fig. 1) is an anadromous form of brown trout - Salmo trutta (Bouza et al., 1999). It belongs to Salmonidae family which includes Atlantic salmon (Salmo salar L.), arctic charr (Salvelinus alpinus L.) and rainbow trout (Oncorhynchus mykiss Walbaum) (Frank-Gopolos et al., 2015). Anadromous fish affect many other species in their environment and have a profound effect on the stability of aquatic and terrestrial ecosystems in which they occur; therefore, they are considered as a 'keystone' species (Willson, Halupka, 1995).

Main threats to anadromous fish populations in Poland are migration barriers, overfishing, poaching, and environmental changes linked with water pollution (HELCOM, 2015; Kazuń et al., 2011; Radtke et al., 2012; "The Valley of Stupia”..., 2017). Another important factor limiting sea trout populations in Poland is Ulcerative Dermal Necrosis (UDN), which is like the disease observed in the Slupia river from 2007 (Grudniewska et al., 2011; Grudniewska et al., 2012; Kazuń et al., 2011). UDN is an infectious skin disease of unknown etiology affecting adult, wild, anadromous salmonids migrating from open seas to fresh water during the spawning season (Bruno et al., 2013; Harris et al., 2011).

First documented mentions of the disease originate from late $19^{\text {th }}$ century Great Britain (Roberts, 1993). In the second half of the XX century, outbreaks were reported in many European countries: Austria, Belgium, France, Luxembourg, Germany, Great Britain, Switzerland, Sweden, and Canada (Grudniewska et al., 2012; Johansson et al., 1982). The highest mortalities are observed in November and December. UDN 


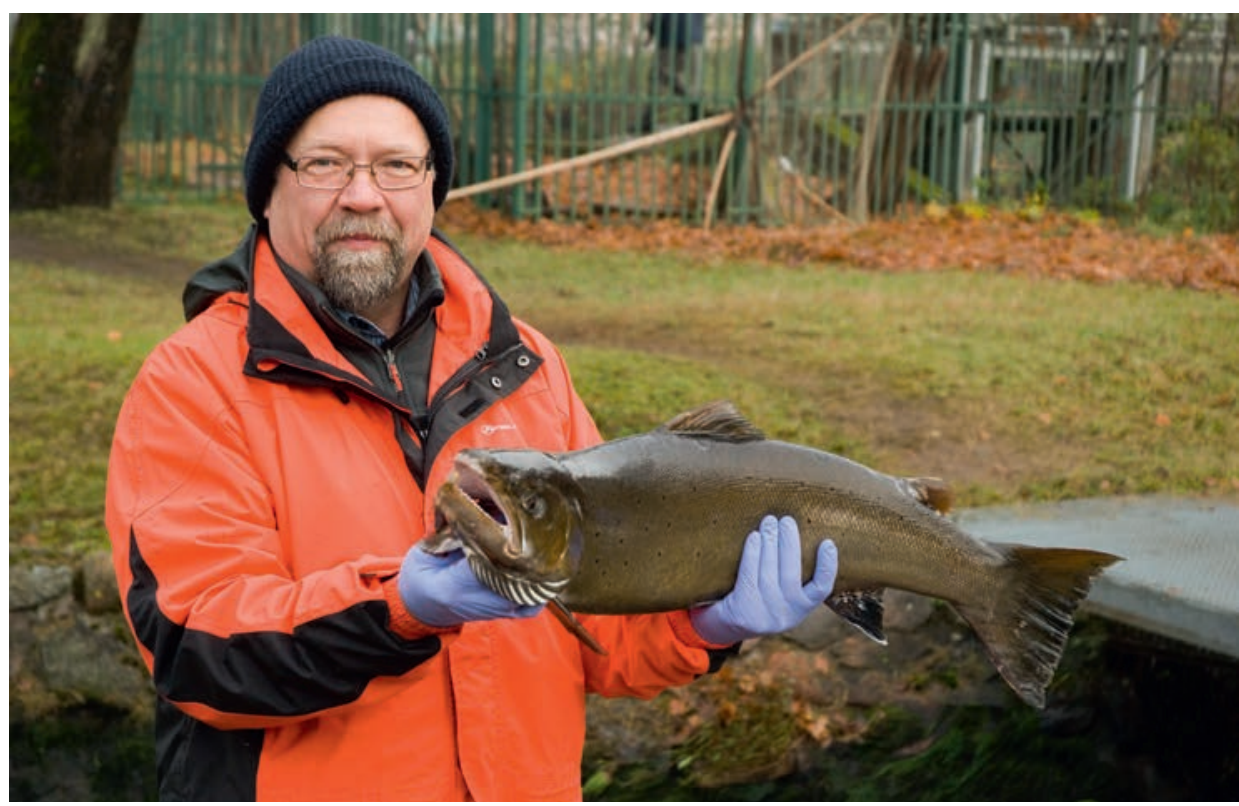

Fig. 1. Sea trout with author for scale (Photo. M. Ciepliński)

occurrence is linked to low water temperature during these months. Large fish concentrations during spawning season create perfect conditions for contagious diseases to spread (Munro, 1970). The first visible signs of UDN are small, grey lesions on the operculum, fins, and head (Bruno et al., 2013). These rapidly ulcerate and frequently become infected with opportunistic pathogens, mainly the oomycete Saprolegnia diclina Humphrey, which has expansive growth that makes skin damage even greater (Roberts, 1993). Such extensive epidermal damage induces osmotic haemodilution leading to circulatory failure and the death of infected fish (Bruno et al., 2013). The Słupia River is one of the first rivers where occurrence of sea trout spawners with UDN-like symptoms was reported (Bartel et al., 2009). Since then, the disease occurrence is observed on a yearly basis ("The Valley of Słupia”, management personal communication).

Tab. 1. Number of healthy, sick and agonal (n) female sea trout Salmo trutta m. trutta L. blood samples used in the present study in each and all years of research

\begin{tabular}{lccccc}
\hline \multirow{2}{*}{ Health status } & \multicolumn{5}{c}{ Year } \\
\cline { 2 - 6 } & 2014 & 2015 & 2016 & 2017 & $2014-2017$ \\
\hline Healthy (1) & 15 & 8 & 1 & 32 & 56 \\
Sick (2) & 8 & 31 & 19 & 5 & 63 \\
Agonal (3) & 8 & 6 & 17 & 0 & 31 \\
Total & 31 & 45 & 37 & 37 & 150 \\
\hline
\end{tabular}


Blood tests are a very valuable tool in human and veterinary medicine. Due to its properties, blood is virtually the easiest tissue to obtain and to test. Blood tests are also one of the most comprehensive ways to assess the status of animal health. Despite rapid development of laboratory techniques, the haematology of fish is still underestimated in the assessment of fish welfare. Many factors influence fish blood results, inter alia, age, sex, reproductive and nutritional status, water temperature, and oxygen concentration ( ̌̌ehulka, Adamec, 2004; Witeska, 2013). Blood tests reference values found in literature are scarce and often vary significantly between reports.

In the present study, the authors decided to investigate the impact of UDN on selected haematological (red blood cell count - RBC, haemoglobin concentration HGB, haematocrit HCT) and biochemical (total protein, albumin and BUN concentration) parameters of female sea trout spawners from the Słupia River during four (2014-2017) consecutive spawning seasons. We assume that, along with health deterioration, selected blood parameters, i.e. RBC, HGB, HCT, and concentrations of total protein, albumin, and blood urea nitrogen (BUN) will change significantly.

\section{Material and methods}

Fish

Mature, spawning sea trout (Salmo trutta $\mathrm{m}$. trutta) females ( $\mathrm{n}=150$ ) (mean mass 2.02 $\pm 0.90 \mathrm{~kg}$, mean length $60.01 \pm 7.64 \mathrm{~cm}$ ) were caught during four consecutive spawning seasons in November 2014-2017 (Tab. 1) on a Polish Angling Association trapping point $\left(54^{\circ} 27^{\prime} 37.4^{\prime \prime} \mathrm{N} ; 17^{\circ} 02^{\prime} 21.1^{\prime \prime} \mathrm{E}\right)$ on the Słupia River, Słupsk, northern Poland. Water temperature during catches ranged between $4.6-8.6^{\circ} \mathrm{C}$ (data provided by "The Valley of Słupia" Landscape Park). All animals with evident signs of a disease were a bycatch of a targeted trapping of healthy spawners necessary for artificial spawning. All specimens were euthanized with blunt force trauma to the cranium region which was followed by pithing by PAA workers. Healthy specimens were euthanized after artificial spawning. All fish used in the present research were donated by the PAA. All applicable international and national guidelines for the care and use of animals were followed by the authors. Blood and other tissues for further examination, not presented in this article, were collected. Photographic documentation of fish skin infection patterns covered both sides of the body. Photographs were made with a Nikon D80 camera.

\section{Health status assessment}

On the basis of photographic documentation, infection schemes were prepared for each UDN affected specimen in the GIMP 2.8.18 software (The GIMP team, www.gimp.org, 1997-2016). All visible areas of damaged skin were mapped on an outline depicting trout contour (Fig. 2A). Salmo trutta m. fario L. illustration (Böhmig, Brauer, 1909) was 

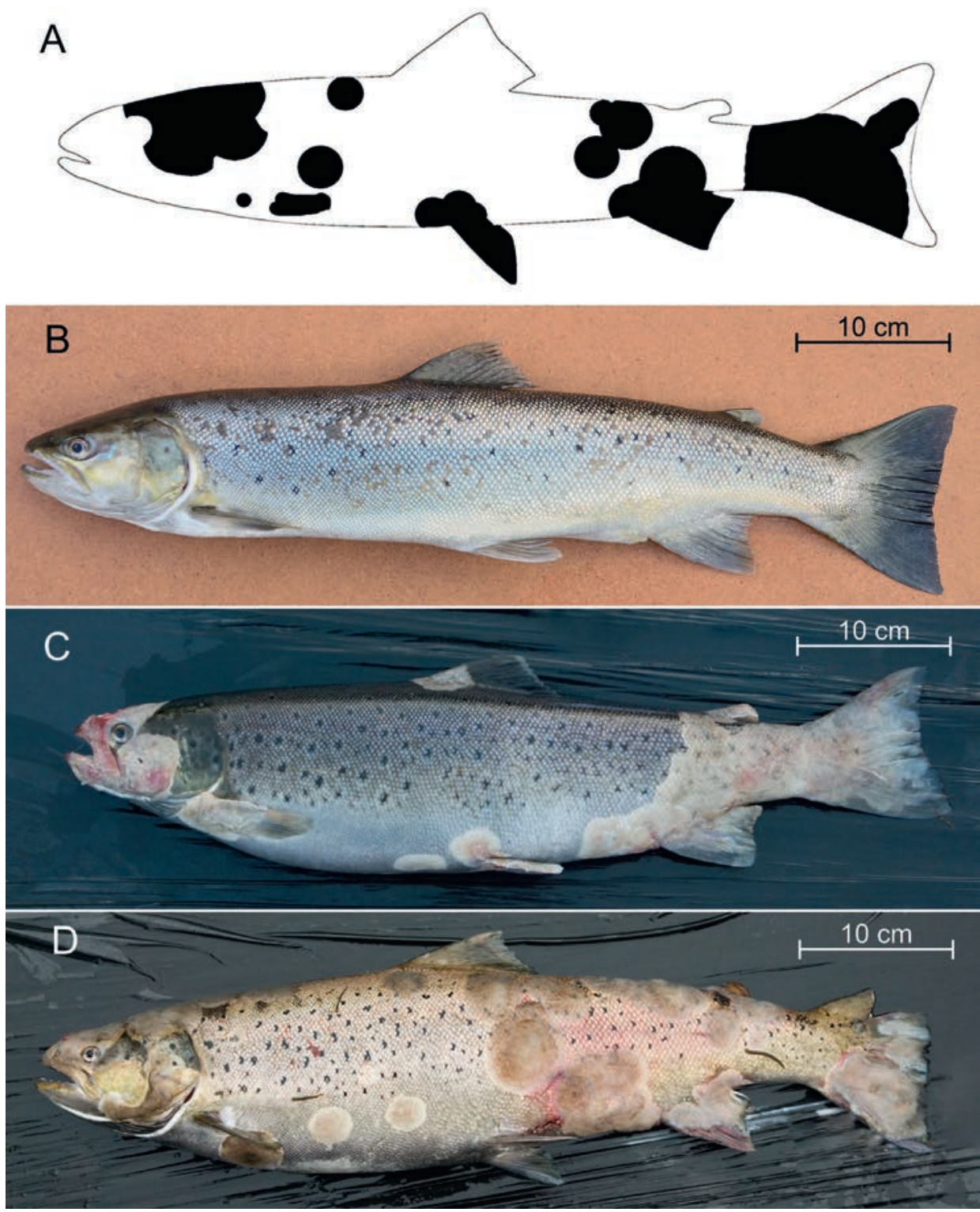

Fig. 2. Salmo trutta m. trutta L.: A - sample (left body side) infection scheme made on the basis of photographic documentation; areas of damaged skin were mapped on an outline depicting trout contour, B Healthy Salmo trutta m. trutta female specimen,; C - sick female specimen, D - agonal female specimen (Photo. M. Ciepliński) 
chosen due to its simplicity. For each specimen, two schemes were prepared (for both sides of the body). Obtained images were then analysed with ImageJ 1.50i (Rasband, 1997) software to determine the percentage of skin damage. Obtained results for both sides of the body were then averaged, due to high bilateral symmetry of lesions.

Skin damage as little as $10 \%$ is known to result in nearly $50 \%$ mortality (Noga, 2000). This fact being known, the authors decided to group fish into three categories (Fig. 2): (2B) healthy specimens with no visible signs of UDN; (2C) sick, where from $0.01 \%$ up to $10 \%$ skin was damaged (mean $=2.77 \%$ ); and, $(2 \mathrm{D})$ agonal, where lesions covered more than $10 \%$ of the body surface $($ mean $=23.94 \%)$.

\section{Laboratory analysis}

Blood for haematological analysis was drawn from caudal vein by means of a $1.2 \times 44 \mathrm{~mm}$ needle and $5 \mathrm{ml}$ syringe. About $8-10 \mathrm{ml}$ of blood in total was obtained from each specimen. We used a minimum two $5 \mathrm{ml}$ syringes, and not one $10 \mathrm{ml}$, because the high vacuum created by such syringe could damage erythrocytes. Immediately after collection, $2 \mathrm{ml}$ of blood was then transferred to standard test tubes containing $\mathrm{K}_{2}$ EDTA ( $1.8 \mathrm{mg} / \mathrm{ml} \mathrm{K}_{2}$ EDTA for $2 \mathrm{ml}$ of blood) (Medlab-Products) for basic haematological analysis. The remaining amount of blood was left to clot in $7 \mathrm{ml}$ conical centrifuge tubes. Clot was then centrifuged to obtain serum for biochemical analysis (total protein, albumin, and BUN concentrations). In 2014, serum samples were not collected. Basic haematological analysis (RBC, HGB, HCT) was performed immediately after collection with use of manual methods. Red blood cell count (RBC) was determined with use of Bürker hemocytometer and Natt and Herrick (1952) stain. Drabkin's (Drabkin, 1945) cyanmethemoglobin method was used to assess haemoglobin concentration (HGB). Hematocrit (HCT) was determined according to Turgeon (2012). Biochemical analysis (total protein, albumin, and blood urea nitrogen concentration (BUN)) was performed with use of an ARCHITECT c 4000 clinical chemistry analyser (Abbott Diagnostics). Unfortunately, on a few samples, concentrations of selected biochemical parameters were beyond the measuring range of the analyser.

\section{Statistics analysis}

Statistical analysis was performed in search for differences in blood parameters between different health status groups. Due to the lack of normal distribution in all presented parameters, Kruskal-Wallis tests for independent groups and were used. Analysis was made with Statistica 12.5 software (StatSoft, 2006). 
A comparison of selected sea trout (Salmo trutta m. trutta, female spawners) hematological parameters in relation to health status is presented in table 2.

Significantly lower RBC counts ( $<<0.05)$, HGB $(\mathrm{p}<0.01)$ and HCT $(\mathrm{p}<0.01)$ were observed in agonal fish than in the remaining two health status groups, between which no statistically significant differences were observed. In total protein $(\mathrm{p}<0.0001)$ and albumin $(\mathrm{p}<0.0001)$ concentrations, all groups differed significantly. In these parameters, a clear value drop is visible along with health status deterioration. Agonal specimens had significantly higher urea concentrations $(\mathrm{p}<0.0001)$ than the other two groups.

Tab. 2. Selected haematological parameters of healthy, sick and agonal sea trout Salmo trutta m. trutta L.; values are mean \pm SD; means in parameters marked with different superscript are significantly different $(\mathrm{p}<0.05)$

\begin{tabular}{|c|c|c|c|c|c|c|}
\hline \multirow[b]{2}{*}{$\begin{array}{l}\text { Health } \\
\text { status }\end{array}$} & \multicolumn{6}{|c|}{ Parameter } \\
\hline & $\begin{array}{l}\text { RBC } \\
{[T / l]}\end{array}$ & $\begin{array}{l}\text { HGB } \\
{[\mathrm{g} / \mathrm{dl}]}\end{array}$ & $\begin{array}{c}\mathrm{HCT} \\
{[\%]}\end{array}$ & $\begin{array}{l}\text { Total protein } \\
{[\mathrm{g} / \mathrm{dl}]}\end{array}$ & $\begin{array}{l}\text { Albumin } \\
\text { [g/dl] }\end{array}$ & $\begin{array}{c}\text { BUN } \\
{[\mathrm{mg} / \mathrm{dl}]}\end{array}$ \\
\hline $\begin{array}{l}\text { Healthy } \\
\text { (1) }\end{array}$ & $\begin{array}{c}1.16 \mathrm{a}^{ \pm} 0.23 \\
\mathrm{n}=56\end{array}$ & $\begin{array}{c}9.79 \mathrm{a}^{ \pm} 1.86 \\
\mathrm{n}=56\end{array}$ & $\begin{array}{c}46.93 \mathrm{a}^{ \pm} 7.52 \\
\mathrm{n}=56\end{array}$ & $\begin{array}{c}5.34 \mathrm{a}^{ \pm} 1.87 \\
\mathrm{n}=40\end{array}$ & $\begin{array}{c}1.81 \mathrm{a}^{ \pm} 0.41 \\
\mathrm{n}=41\end{array}$ & $\begin{array}{c}4.63 \mathrm{a}^{ \pm} 1.48 \\
\mathrm{n}=40\end{array}$ \\
\hline $\begin{array}{l}\text { Sick } \\
\text { (2) }\end{array}$ & $\begin{array}{c}1.18 \mathrm{a}^{ \pm} 0.26 \\
\mathrm{n}=63\end{array}$ & $\begin{array}{c}10.20 \mathrm{a}^{ \pm} 1.64 \\
\mathrm{n}=63\end{array}$ & $\begin{array}{c}46.28 \mathrm{a}^{ \pm} 6.98 \\
\mathrm{n}=63\end{array}$ & $\begin{array}{c}3.35 b^{ \pm} 1.13 \\
n=52\end{array}$ & $\begin{array}{c}1.52 b^{ \pm} 0.45 \\
n=52\end{array}$ & $\begin{array}{c}4.74 \mathrm{a}^{ \pm} 1.70 \\
\mathrm{n}=63\end{array}$ \\
\hline $\begin{array}{l}\text { Agonal } \\
\text { (3) }\end{array}$ & $\begin{array}{c}1.02 \mathrm{~b}^{ \pm} 0.27 \\
\mathrm{n}=31\end{array}$ & $\begin{array}{c}8.95 b \pm 3.87 \\
n=31\end{array}$ & $\begin{array}{c}38.61 b^{ \pm} 1.87 \\
\mathrm{n}=31\end{array}$ & $\begin{array}{c}1.31 \mathrm{c}^{ \pm} 0.46 \\
\mathrm{n}=17\end{array}$ & $\begin{array}{c}0.64 c^{ \pm} 0.25 \\
n=16\end{array}$ & $\begin{array}{c}6.74 b^{ \pm} 1.65 \\
n=31\end{array}$ \\
\hline
\end{tabular}

Note: RBC - red blood cell count, HGB - haemoglobin concentration, HCT - haematocrit, BUN - blood urea nitrogen

\section{Discussion}

Skin integrity is vital for the maintenance of fish homeostasis. In a fresh water environment, it prevents water intake, which is consistent with concentration gradient. The damage caused by infection development disturbs this property (Noga, 2000). Uncontrolled water uptake leads to the decrease in hematologic parameters. A similar effect is observed in total protein and albumin concentrations, both of which help to maintain proper colloid osmotic pressure (Harr, 2006). Although this parameter was not determined in the current study, globulin concentration, which is a difference between total protein and albumin concentrations, would also decrease indicating immunodeficiency (Thrall et al., 2012), and elevated blood urea nitrogen in fish is a sign of gill dysfunction (Nelson et al., 1999).

In the present study, results show that skin damage of more than $10 \%$ leads to severe hemodilution and a significant drop in investigated haematological parameters 
(RBC, HGB, HCT). A slight increase in HGB observed in sick fish, as compared to healthy fish, may suggest that, during the first stages of UDN-like infection, the fish organism is trying to defend itself from hypoxia caused by developing respiratory failure (Affonso et al., 2002). The decrease of HTC, in relation to disease development, is the consequence of excessive water uptake via damaged skin and drop in red blood cell count (Weiss, Wardrop, 2010). Even slight, superficial skin damage (less than 10\% of body surface) leads to a significant decrease in total serum protein and albumin concentrations directly caused by water influx (Harr, 2006). This effect is even greater in severely diseased fish. The aftermath of gill damage is an increase in BUN concentration (Nelson et al., 1999).

Due to many factors influencing fish blood results (i.e. age, sex, reproductive and nutritional status, water temperature, oxygen concentration) (Řehulka, Adamec, 2004; Witeska, 2013), normal values that have been presented could serve as reference only for healthy female sea trout during the spawning season.

\section{Acknowledgements}

The research was entirely funded by Faculty of Biological Sciences, University of Zielona Góra. We would like to thank the management and staff of "The Valley of Słupia" Landscape Park for help and support during fieldwork, as well as the Polish Angling Association of the district of Słupsk for providing essential research material.

\section{References}

Affonso, E.G., Polez, V.L.P., Corrêa, C.F., Mazon, A.F., Araújo, M.R.R., Moraes, G., Rantin, F.T. (2002). Blood parameters and metabolites in the teleost fish Colossoma macropomum exposed to sulfide or hypoxia. Comparative Biochemistry and Physiology Part C: Toxicology \& Pharmacology, 133(3), 375-382. DOI: 10.1016/S1532-0456(02)00127-8

Bartel, R., Bernaś, R., Grudniewska, J., Jesiołowski, M. (2009). Furunculosis in salmon (Salmo salar) and sea trout (Salmo trutta trutta) in Poland in 2007 and 2008. Komunikaty Rybackie, 110(3), 7-13.

Böhmig, L., Brauer, A. (1909). Die Süsswasserfauna Deutschlands: Eine Exkursionsfauna Heft 1: Mammalia, Aves, Reptilia, Amphibia, Pisces. Germany, Jena: Verlag von Gustav Fischer. https://archive.org/ details/diessswasserfa01brau [In German]

Bouza, C., Arias, J., Castro, J., Sanchez, L., Martinez, P. (1999). Genetic structure of brown trout, Salmo trutta L., at the southern limit of the distribution range of the anadromous form. Molecular Ecology, 8(12), 1991-2001. DOI: 10.1046/j.1365-294x.1999.00794.x

Bruno, D., Noguera, P.A., Poppe, T.T. (2013). A colour atlas of salmonid diseases (2nd ed.). Netherlands: Springer Science \& Business Media.

Drabkin, D.L. (1945). Crystallographic and optical properties of human hemoglobin - a proposal for the standardization of hemoglobin. American Journal of the Medical Sciences, 209, 268-270.

Frank-Gopolos, T., Bekkevold, D., Guyomard, R., De Innocentiis, S., Martínez Portela, P., Fernández, C., Vera, M. (2015). AquaTrace species leaflet - Brown trout (Salmo trutta). https://aquatrace.eu/ leaflets/trout

Grudniewska, J., Bartel, R., Bernaś, R., Ciżmowski, L., Jesiołowski, M., Kacperska, B., Siwicki, A.K. (2011). Pathological changes in the skin of salmon, Salmo salar, and sea trout, Salmo trutta trutta, spawners from some Pomeranian rivers in 2009. Komunikaty Rybackie, 121(2), 7-12. 
Grudniewska, J., Bartel, R., Terech-Majewska, E., Kazuń, B., Siwicki, A.K. (2012). Evaluation of abundance, condition, and health of sea trout (Salmo trutta trutta) and salmon (Salmo salar) spawners threatened with UDN in some Polish rivers in 2010. Komunikaty Rybackie, 130(5), 1-7.

Harr, K.E. (2006). Diagnostic Value of Biochemistry. In: G.J. Harrison, T.J. Lightfoot (eds.), Clinical avian medicine I. Palm Beach, USA: Spix Publishing.

Harris, P.D., Bachmann, L., Bakke, T.A. (2011). The parasites and pathogens of the Atlantic salmon: lessons from Gyrodactylus salaris. Atlantic Salmon Ecology, 221-252. DOI: 10.1002/9781444327755.ch9

HELCOM (2015). Abundance of sea trout spawners and parr. HELCOM core indicator report. http:// www.helcom.fi/baltic-sea-trends/indicators/abundance-of-sea-trout-spawners-and-parr

Johansson, N., Svensson, K.M., Fridberg, G. (1982). Studies on the pathology of ulcerative dermal necrosis (UDN) in Swedish salmon, Salmo salar L., and sea trout, Salmo trutta L., populations. Journal of Fish Diseases, 5(4), 293-308.

Kazuń, B., Grudniewska, J., Terech-Majewska, E., Kazuń, K., Głąbski, E., Siwicki, A.K. (2011). Health assessments of sea trout, Salmo trutta trutta, spawners from Pomeranian rivers in 2010 based on immunological examinations. Komunikaty Rybackie, 124(5), 1-4.

Munro, A.L.S. (1970). Ulcerative dermal necrosis, a disease of migratory salmonid fishes in the rivers of the British Isles. Biological Conservation, 2(2), 129-132. DOI: 10.1016/0006-3207(70)90148-5

Natt, M.P., Herrick, C.A. (1952). A new blood diluent for counting the erythrocytes and leucocytes of the chicken. Poultry Science, 31(4), 735-738. DOI: 10.3382/ps.0310735

Nelson, K., Jones, J., Jacobson, S., Reimschuessel, R. (1999). Elevated blood urea nitrogen (bun) levels in goldfish as an indicator of gill dysfunction. Journal of Aquatic Animal Health, 11(1), 52-60. DOI: 10.1577/1548-8667(1999)011<0052:EBUNBL>2.0.CO;2

Noga, E.J. (2000). Skin ulcers in fish: pfiesteria and other etiologies. Toxicologic Pathology, 28(6), 807-823. DOI: $10.1177 / 019262330002800607$

Radtke, G., Bernaś, R., Skóra, M. (2012). Small hydropower stations - major ecological problems: some examples from rivers of northern Poland. Chrońmy Przyrodę Ojczysta, 68(6), 424-434.

Rasband, W.S. (1997). Image J, U. S. National Institutes of Health (Version 1.50I). Maryland, USA: Bethesda. https://imagej.nih.gov/ij/

Řehulka, J., Adamec, V. (2004). Red blood cell indices for Rainbow Trout (Oncorhynchus mykiss) reared in cage and raceway culture. Acta Veterinaria Brno, 73(1), 105-114. DOI: 10.2754/avb200473010105

Roberts, R.J. (1993). Ulcerative dermal necrosis (UDN) in wild salmonids. Fisheries Research, 17(1-2), 3-14. DOI: 10.1016/0165-7836(93)90003-P

StatSoft (2006). Elektroniczny Podręcznik Statystyki PL. Kraków, Poland. http://www.statsoft.pl/textbook/stathome.html [In Polish]

"The Valley of Stupia" Landscape Park (2017). Protection of Migratory Fish. http://dolinaslupi.pl/ czynna-ochrona/ochrona-ryb-wedrownych/

Thrall, M.A., Weiser, G., Allison, R., Campbell, T. (2012). Veterinary Hematology and Clinical Chemistry (2nd ed.). Ames, USA: Wiley-Blackwell.

Turgeon, M.L. (2012). Clinical Hematology: Theory and Procedures (5th ed.). Baltimore, USA: Lippincott Williams \& Wilkins.

Weiss, D.J., Wardrop, K.J. (2010). Schalm's Veterinary Hematology (6 edition). Ames, USA: Wiley-Blackwell.

Willson, M.F., Halupka, K.C. (1995). Anadromous Fish as Keystone Species in Vertebrate Communities. Conservation Biology, 9(3), 489-497. DOI: 10.1046/j.1523-1739.1995.09030489.x

Witeska, M. (2013). Erythrocytes in teleost fishes: a review. Zoology and Ecology, 23(4), 275-281. DOI: $10.1080 / 21658005.2013 .846963$ 


\begin{abstract}
Blood tests were performed on 150 female sea trouts Salmo trutta m. trutta L. during four spawning seasons (2014-2017). Fish were caught on a Polish Angling Association trapping point, the Słupia River, Słupsk (northern Poland). The blood for analysis was drawn from caudal vein of 56 healthy and 94 UDN (Ulcerative Dermal Necrosis) infected females. Fish were divided into three groups: (1) healthy, with no visible signs of UDN; (2) sick, with up to $10 \%$ skin damage; and, (3) agonal, where more than $10 \%$ of body surface was infected. A statistically important decrease in red blood cell count (RBC), haemoglobin concentration (HGB) and haematocrit (HCT) were found between sick and agonal fish groups. The concentration of total plasma protein and albumin decreased in relation to fish health deterioration. Blood urea nitrogen (BUN) had an inverse proportionality to total plasma protein and albumin concentration. Based on the decrease of RBC, HGB, and HCT due to the development of UDN symptoms, a decrease in fish condition was observed. Significantly higher urea concentrations observed in agonal fish may indicate respiratory and excretory systems failure.
\end{abstract}

Key words: blood, haematology, sea trout, Ulcerative Dermal Necrosis

Received: [2018.06.29]

Accepted: [2018.12.10]

\title{
Wpływ UDN na wybrane parametry krwi samic troci wędrownej
} Salmo trutta m. trutta L. w czasie tarła

\section{Streszczenie}

W latach 2014 do 2017 w czterech sezonach rozrodczych przeprowadzono badania krwi na 150 samicach troci wędrownej Salmo trutta m. trutta L. Ryby odłowiono na Punkcie Odłowu Troci na rzece Słupi w Słupsku (północna Polska). Z żyły ogonowej pobrano krew od 56 zdrowych oraz 94 chorych na UDN (Ulcerative Dermal Necrosis - wrzodziejąca martwica skóry) samic. Badane osobniki podzielono na 3 grupy: (1) zdrowe bez widocznych objawów UDN, (2) chore ze zmianami do $10 \%$ powierzchni ciała oraz (3) agonalne, gdzie więcej niż $10 \%$ powierzchni ciała zostało uszkodzone. Istotne statystycznie zmniejszenie wartości liczby krwinek czerwonych (RBC), stężenia hemoglobiny (HGB) oraz hematokrytu (HCT) stwierdzono pomiędzy osobnikami chorymi i agonalnymi. Stężenie białka całkowitego oraz albumin zmniejszało się istotnie statystycznie wraz z pogorszeniem stanu zdrowia ryb. Stężenie mocznika zmieniało się odwrotnie proporcjonalnie do stężenia białka i albumin. Wraz ze wzrostem intensywności rozwoju UDN stwierdzono osłabienie kondycji wyrażające się zmniejszeniem RBC, HGB jak i HCT. Znacznie wyższe stężenie BUN u ryb agonalnych może wskazywać na niewydolność układu oddechowego i wydalniczego.

Słowa kluczowe: krew, hematologia, troć wędrowna, wrzodziejąca martwica skóry UDN

\section{Information on the authors}

Mateusz Ciepliński http://orcid.org/0000-0002-3386-9744

$\mathrm{He}$ is a PhD student and a scientific-technical worker on the Faculty of Biological Sciences, University of Zielona Góra. His research interests focuses on vertebrate haematology and its practical application in veterinary medicine.

Mariusz Kasprzak http://orcid.org/0000-0001-9088-8098

$\mathrm{He}$ is focused on the relationship between the quality of the environment and the condition of the animals, and is an assistant professor in the Department of Zoology at the Faculty of Biological Sciences, University of Zielona Góra.

Monika Grandtke http://orcid.org/0000-0001-9472-252X

She is a PhD student at the Faculty of Biological Sciences at the University of Zielona Góra. She works at the University of Zielona Góra as a scientific and technical assistant. She is interested in the influence of the environment with varying degrees of pollution on the white and red blood cell parameters of storks. 
Aleksandra Steliga http://orcid.org/0000-0002-2153-9414

She is a PhD student at Gdański Uniwersytet Medyczny in Gdańsk. She works at the Department of Health Sciences on Pomeranian University in Słupsk and is interested in the haematology of vertebrates and human glial cells.

Piotr Kamiński http://orcid.org/0000-0003-1978-6018

He is an assistant professor in the Department of Biotechnology at the Faculty of Biological Sciences, University of Zielona Góra and Nicolaus Copernicus University in Toruń, Collegium Medicum in Bydgoszcz. He is fascinated by animal ecophysiology.

Leszek Jerzak http://orcid.org/0000-0001-5332-279X

He is full professor in nature protection at the University of Zielona Góra, Poland (Faculty of Biological Sciences). He studies the biology and ecology of animals (especially the White Stork and the Magpie) and co-operates with research centres in Germany, USA, Ireland, and Russia. 